\title{
Physicochemical and sensory characteristics of snack made with minced Nile tilapia
}

\author{
João de Paula CORTEZ NETTO ${ }^{1}$, Paulo Roberto Campagnoli de OLIVEIRA FILHO ${ }^{1}$, \\ Judite LAPA-GUIMARÃES ${ }^{1}$, Elisabete Maria Macedo VIEGAS ${ }^{1 \star}$
}

\begin{abstract}
Nile tilapia is one of the major fish species cultivated worldwide and in Brazil. The tilapia fillet yield is between 30-35\%, thus around $70 \%$ of waste is generated. A portion of this waste can be used to obtain minced fish, and the resulting product can be used as meat raw material to prepare fish snacks. The aim of this study was to produce fish snacks containing different inclusion levels $(20,30$, and $40 \%)$ of minced fish obtained from Nile tilapia processing waste and evaluate their physicochemical characteristics and sensory acceptance. Protein content, ash, water activity, and hardness increased with increasing inclusion of minced fish. The scores obtained in the sensory evaluation were: flavor acceptance (from 7.2 to 5.7), texture (from 7.4 to 5.3), overall acceptance (from 7.1 to 5.9), and willingness to purchase (from 4.0 to 3.1). This study demonstrates that the inclusion of 20 to $40 \%$ of minced fish of Nile tilapia in snacks is well accepted and improves their nutritional value without affecting the physicochemical properties.
\end{abstract}

Keywords: Oreochromis niloticus; waste recovery; fish processing; sensory evaluation.

\section{Introduction}

Snacks made with minced fish (MF) are known worldwide as fish crackers (Food and Agriculture Organization, 2001) and are widely consumed in Asian countries including Malaysia, Indonesia, Thailand, and Vietnam (Nurul et al., 2009; Taewee, 2011). It is an appetizer made from starch (cassava, potato, corn, rice, tapioca, wheat, sago or beans) mixed with MF (Nurul et al., 2009).

Most of the fish snack production is still homemade, but over the last decade, companies have invested in technology to increase production and improve quality (Nurul et al., 2001; Taewee, 2011). There are several types and formulations of snacks; the main difference is the MF/starch ratio (Siaw et al., 1985). Furthermore, MF from various types of fish can be used together with seasonings, salt, and sugar to produce different snacks. (Nurul et al., 2001).

Starch is the main ingredient responsible for the expansion and crispness of snacks (Taewee, 2011). However, the MF may inhibit starch gelatinization, thus reducing the product expansion (Dehghan-Shoar et al., 2010). Therefore, it is important to determine the optimal of MF/starch ratio to produce fish snacks with better physicochemical and sensory characteristics.

Nile tilapia is the main freshwater fish cultivated in Brazil (Brasil, 2011). The tilapia fillet (main form of processing) yield is between $30-35 \%$, thus generating around $70 \%$ of waste. A portion of this waste can be used to obtain minced fish using a meat/bone separator, and the resulting product can be used as meat raw material to prepare a wide variety of products (Oliveira Filho et al., 2010). MF from marine fish has been used to produce snack fish, such as soldier croaker (Johnius soldado) (Kyaw et al., 2001), bigeye grunt (Brachydeuterus auritus) (King, 2002) snapper (Lutjanus spp), giant snakedead (Ophiocephalus micropeltes), hake (Merluccius gayi) (Rado et al., 1989), cod (Gadus morhua) (Shaltout, 1993; Cheow et al., 1999) and Siena spp (Cheow \& Yu, 1997). However, studies on the use of MF from tilapia as raw material for snack preparation are not available in literature.

The aim of this study was to produce fish snacks containing different levels (20,30 and 40\%) of MF obtained from Nile tilapia processing waste and evaluate their physicochemical characteristics and sensory acceptance.

\section{Materials and methods}

A total of $150 \mathrm{~kg}$ carcasses of Nile tilapia (Oreochromis niloticus) were cleaned according to good manufacturing practices and then processed in a meat/bone separator with endless worm gear (HT 250, High-Tech, Chapecó, Santa Catarina, Brazil). The minced fish with approximately 59\% yield was mixed manually with $0.5 \%$ antioxidant (Doremus Alimentos Ltda, Guarulhos, São Paulo, Brazil). Subsequently, $500 \mathrm{~g}$ of MF were packaged in plastic bags and frozen in a ultrafast plate freezer (UCE - 20 Eco, São Paulo, São Paulo, Brazil) for about 90 min until the internal temperature reached $-40^{\circ} \mathrm{C}$ and stored at $-18^{\circ} \mathrm{C}$ until the snack preparation (approximately one month).

Three treatments with different $\mathrm{MF} /$ starch ratios were evaluated: $20 \%$ MF and 80\% starch; 30\% MF and 70\% starch; and $40 \% \mathrm{MF}$ and $60 \%$ starch. The starch source was a mixture of $60 \%$ sour starch and $40 \%$ corn flour. For all treatments, $2 \%$ salt was added. The formulations were calculated to obtain $7 \mathrm{~kg}$ of snack in each treatment. The water content was standardized as $60 \%$ in the formulation with the lowest level of MF inclusion (20\% MF). For the other formulations, water content was 
adjusted according to the moisture content of the ingredients (53.79\% for $30 \% \mathrm{MF}$, and $47.58 \%$ for $40 \% \mathrm{MF}$ ) (Table 1).

Raw corn flour (Yoki Alimentos, Cambará, Paraná, Brazil) was mixed with water and cooked to obtain a firm and homogeneous dough. After cooling, the corn flour was manually mixed with the other ingredients: MF, salt, and sour starch. A cylindrical dough of approximately $45 \mathrm{~g}$ and $10 \mathrm{~cm}$ long without casing (or any material enclosing it) was obtained using a meat grinder coupled with a sausage stuffer equipment. The dough was cooked in water at $100^{\circ} \mathrm{C}$ for 10 minutes, cooled, and dried. It was stored $\left(7^{\circ} \mathrm{C}\right)$ until achieving uniform drying and allow slicing. The dough was then sliced (1.5 $\mathrm{mm}$ thickness) using a meat slicer (Gural, São José dos Pinhais, Paraná, Brazil), and the slices were dried (Fanem, São Paulo, São Paulo, Brazil) at $55^{\circ} \mathrm{C}$ for about 2 hours; $300 \mathrm{~g}$ of the product were cooled at room temperature, wrapped in plastic films and stored at $25 \pm 0.3^{\circ} \mathrm{C}$ until analysis. The snacks were deep fried in soybean oil at $200{ }^{\circ} \mathrm{C}$ for 4 seconds.

Moisture content, lipids, proteins, and minerals of the minced fish, dough, and the fried and non-fried snacks were determined in triplicate according to AOAC (Association of Official Analytical Chemistry, 1999). The carbohydrate content was estimated by subtracting total percentage of moisture, ash, protein, and lipids from 100, and the caloric value was calculated based on the coefficients of digestibility of proteins, carbohydrates, and lipids, corresponding to 4,4 , and $9 \mathrm{kcal} / \mathrm{g}$, respectively (Instituto Adolfo Lutz, 2008).

Sixty untrained panelists of both sexes participated in the sensory evaluation to estimate the acceptance of the snacks after frying. The experimental design was a balanced complete block, in which each assessor represented one block (Meilgaard et al., 1999). The attributes evaluated were flavor, texture, color, odor, and overall acceptance using a 9-point hedonic scale (1 - extremely dislike to 9 - extremely like). A willingness to purchase test was also conducted using a 5-point scale ( 1 - definitely not buy to 5 - certainly buy). Five samples of each treatment were coded and served to the assessors, using a balanced monadic serving. Sensory analysis was conducted after one week of storage, after verification of microbiological safety for Salmonella sp, Staphylococcus coagulase positive and total coliforms according to APHA (American Public Health Association, 1992) (Samonella sp and Staphylococcus coagulase positive were not detected in $25 \mathrm{~g}$ of sample, and total coliforms was $<3.0$ Most Probable Number $-\mathrm{MPN} \mathrm{g}^{-1}$ all treatments). This study was approved by the Research Ethics Committee (Protocol \# 937/2010).

Table 1. Formulation of $7 \mathrm{~kg}$ of snack varying the of minced fish MF/ starch ratio

\begin{tabular}{lccc}
\hline \multirow{2}{*}{ Ingredients } & \multicolumn{3}{c}{ MF/starch Ratio (kg) } \\
\cline { 2 - 4 } & $20 / 80^{1}$ & $30 / 70^{2}$ & $40 / 60^{3}$ \\
\hline Sour starch (starch - 60\%) & 3.29 & 2.88 & 2.47 \\
Corn flour (starch - 40\%) & 2.19 & 1.92 & 1.64 \\
Minced fish (MF) & 1.37 & 2.05 & 2.74 \\
Salt (2\%) & 0.14 & 0.14 & 0.14 \\
\hline
\end{tabular}

${ }^{1} 60 \%$ water added; ${ }^{2} 53.79 \%$ water added; ${ }^{3} 47.58 \%$ water added.
Water activity was determined in triplicate in an Aqualab CX-2 (Decagon Devices, Pullman, USA) at $25 \pm 1{ }^{\circ} \mathrm{C}$ using $10 \mathrm{~g}$ of non-fried snacks for each treatment, which were prehomogenized in a food processor. Texture analysis was carried out on 25 fried snacks for each treatment using a texture analyzer (TA-XT2i, Stable Micro Systems, Godalming, UK), which was previously calibrated with a $5 \mathrm{~kg}$ calibration weight. The snacks were compressed by a probe blade with knife (HDP / BSK), using pre-test speed and post-test speed of $10 \mathrm{mms}^{-1}$ and distance of $15 \mathrm{~mm}$. Hardness (g. distance ${ }^{-1}$ ) was assessed using the Exponent Lite Express software (4.0.13.0). Oil absorption was evaluated in 10 samples for each treatment. The snacks were weighted individually using an analytical balance (BEL Engineering Mark 210A, Belo Horizonte, Minas Gerais, Brazil) before and after frying in soybean oil at $200{ }^{\circ} \mathrm{C}$. The samples were dried at $100^{\circ} \mathrm{C}$ for 24 hours (Nurul et al., 2009), and the percentage of oil absorption was calculated (Equation 1).

Absorption $(\%)=\left(\frac{\text { sample weight before frying }- \text { sample weight after frying }}{\text { sample weight after frying }}\right) \times 100$

Data were analyzed by a completely randomized design with three treatments (20:80, 30:70 and 40:60 MF of tilapia to starch). Analysis of variance was used after verifying normality of errors and homogeneity of variances. Tukey's test at a $5 \%$ significance level was performed. Orthogonal polynomial contrasts $\left(1^{\text {st }}, 2^{\text {nd }}\right.$, and $3^{\text {rd }}$ degree) were used for comparison between treatments. All data were analyzed using the SAS statistical software version 9.1.3 $\left(\mathrm{SAS}^{\oplus}, 2002\right)$.

\section{Results and discussion}

Increasing the amount of minced fish in the dough prior to processing increased the moisture content (from 49.1 to $53.90 \%$, $\mathrm{P}<0.001$ ), crude protein (from 3.25 to $4.37 \%, \mathrm{P}<0.05$ ), and fat content (from 1.39 to $3.00 \%, \mathrm{P}<0.01$ ). On the other hand, ash content did not change, with values ranging from 1.44 to $1.82 \%$ ( $\mathrm{p}>0.05)$ (Table 2).

The moisture content of the snacks before frying decreased ( $\mathrm{P}<0.01$ ) from 9.71 to $7.46 \%$ with the inclusion of 20 to $40 \%$ minced fish (Figure 1a). Considering that the formulation with $20 \%$ MF contained less water before drying; one possible explanation is that the higher moisture content after drying is related to the higher percentage of starch sources. Starch sources have higher water holding capacity compared to that of MF (Barreto \& Beirão, 1999), which could have prevented moisture

Table 2. Chemical composition of the snack dough* and the minced fish (MF) of Nile tilapia

\begin{tabular}{ccccc}
\hline \multicolumn{5}{c}{ Chemical composition (\%) } \\
\hline Treatment & Moisture & Protein & Lipids & Ash \\
\hline $20 / 80$ & $49.41 \mathrm{c}$ & $3.25 \mathrm{~b}$ & $1.39 \mathrm{c}$ & $1.61 \mathrm{a}$ \\
$30 / 70$ & $50.80 \mathrm{~b}$ & $3.99 \mathrm{ab}$ & $2.16 \mathrm{~b}$ & $1.44 \mathrm{a}$ \\
$40 / 60$ & $53.90 \mathrm{a}$ & $4.37 \mathrm{a}$ & $3.00 \mathrm{a}$ & $1.82 \mathrm{a}$ \\
Minced & 74.2 & 13.14 & 10.95 & 1.13 \\
\hline
\end{tabular}

Means followed by the same letter in columns do not differ by Tukey's test at $5 \%$ significance level. ${ }^{*}$ Mixture of ingredients without processing stages (cooking, drying, cutting, and frying). 
evaporation during the drying process. The fried snack samples had similar moisture content, ranging from 3.07 to $4.52 \%$, and no difference was observed $(\mathrm{P}>0.05)$ with the inclusion of MF. Literature suggests moisture contents varying from 8 to $14 \%$ before frying to obtain the best technological and sensory results for fish snacks (Food and Agriculture Organization, 2001; Taewee, 2011). When comparing the snacks made with MF of tilapia, it is observed that the moisture content of the non-fried snack containing 20-30\% MF reached a minimum of $8 \%$ moisture content, while the fried snack did not reach the minimum moisture content suggested by FAO for all treatments (Food and Agriculture Organization, 2001). In other studies on fried fish snacks, great variations in moisture content are observed, ranging from 0.48 to $12 \%$ (Yu et al., 1981; King, 2002;
Nurul et al., 2009, 2010; Neiva et al., 2011). This discrepancy may be due to the different formulations and types of fish used in the studies. Controlling the moisture content in snacks is necessary to optimize the quality of the resulting product (Nurul et al., 2010). Insufficient water can lead to incomplete gelatinization of starch during the baking process (Nurul et al., 2010), reducing the expansion. However, excessive water can also cause a reduced expansion, resulting in a thinner and less crisp snack or in very soft dough, which is difficult to cut (Nurul et al., 2010).

The protein content of the non-fried and fried snacks increased $(\mathrm{P}<0.01)$ with increasing inclusion of $\mathrm{MF}$ (from $5.89 \%$ to $9.86 \%$ and from $5.14 \%$ to $8.78 \%$, respectively) (Figures $1 \mathrm{~b}, \mathrm{c}$ ).
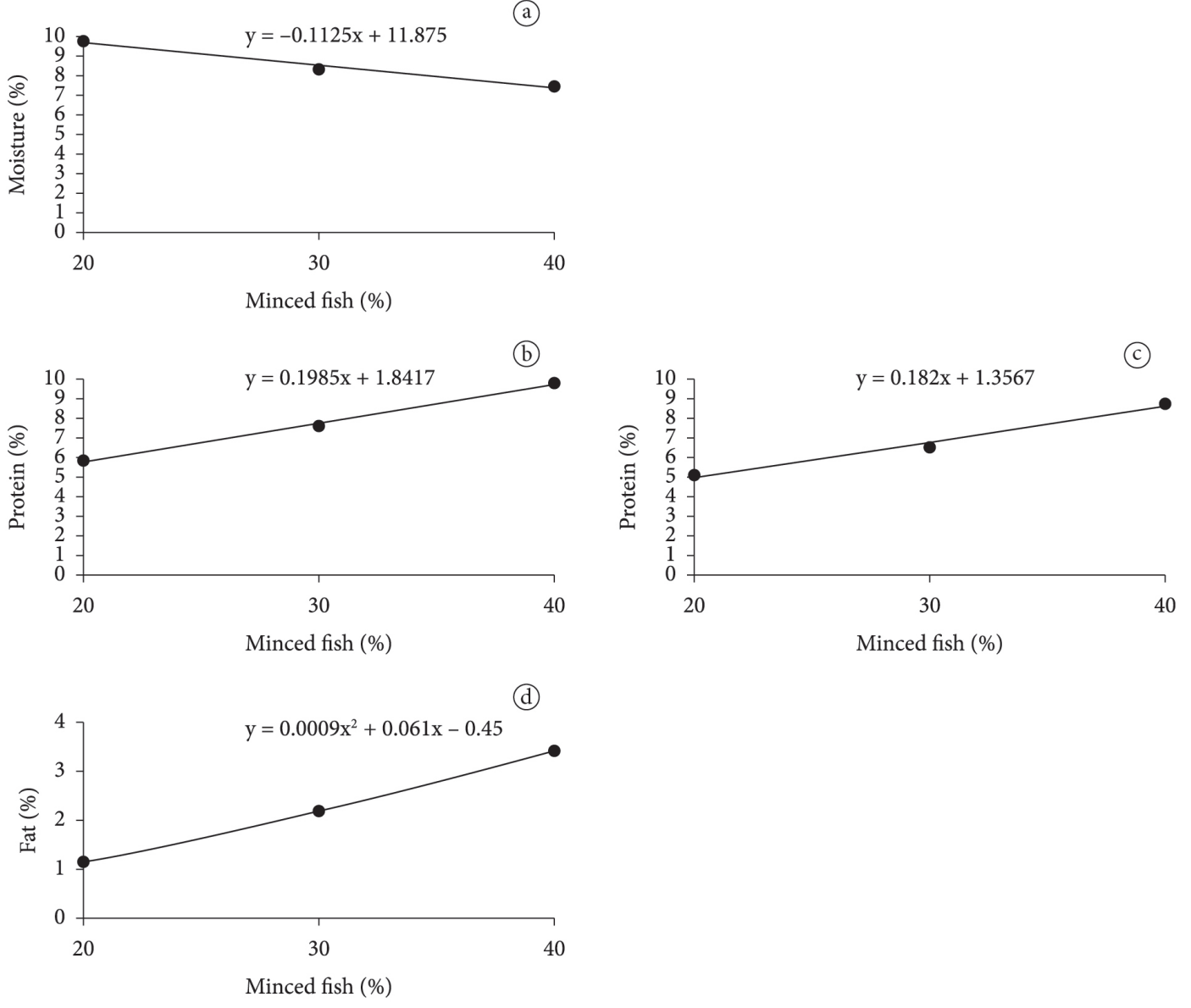

(d)
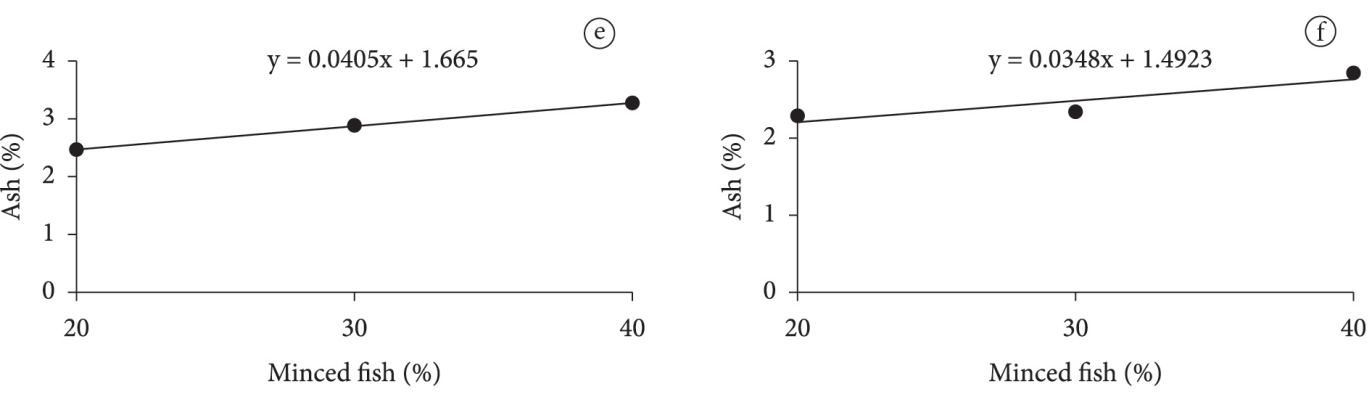

Figure 1. Changes in contents of moisture (a), protein (b), fat (d), and ash (e) of non-fried fish snacks (left) and protein (c) and ash (f) of fried (right) fish snacks with 20 to $40 \%$ inclusion of MF of Nile tilapia. The contents of moisture and fat of the fried snacks were not affected by MF inclusion. 
This increase occurred because MF contains higher protein content than that of starches, and the inclusion of higher levels of MF leads to an increase in the protein content of the product (Yu et al., 1981; King, 2002; Nurul et al., 2009, 2010). FAO recommends that non-fried snacks should contain at least $12 \%$ crude protein (Food and Agriculture Organization, 2001). Although the non-fried and fried snacks of the present study had protein content below the recommended value, in all treatments, the inclusion of MF provided nutritional improvement since starch is the main ingredient of snacks. To meet the protein requirements established by FAO, the inclusion of MF of tilapia in fried snacks should be approximately $45 \%$. However, preliminary tests have proven that it was not possible to produce snacks with inclusions of up to $40 \%$ MF due to the difficulty in obtaining an easy to slice cylindrical dough. In other studies on fish fried snack, protein content varied from 13 and $21 \%$ (Yu et al., 1994; Siaw et al., 1985), thus meeting the protein level recommended by FAO.

The fat content of the non-fried snack increased $(\mathrm{P}<0.01)$ from $1.13 \%$ to $3.43 \%$ with the inclusion of 20 to $40 \%$ MF, which can be due to the fat content of MF (Figure 1d). However, after frying, fat contents were similar, and there was no difference $(\mathrm{P}>0.05)$ in the fat content with the inclusion of 20 to $40 \%$ MF, with average values of $16.53 \pm 3.33 \%$. The fat contents found in the present study are higher than the values reported by Siaw et al. (1985) (from 1 to 1.6\%), King (2002) (from 0.5 to $1.9 \%$ ), Nurul et al. (2010) (from 0.60 to $3.38 \%$ ), Nurul et al. (2009) (from 0.99 to 2.7\%), and lower than the values found by Yu et al. (1994) (from 20 to 30.3\%) and Neiva et al. (2011) (26.11\%). These variations may be due to changes in the fat absorbed by the snacks during frying as a result of factors such as type of meat raw material, fish species, and inclusion levels of the ingredients (Nurul et al., 2010).

The inclusion of MF increased the ash content of both non-fried and fried snacks from $2.47 \%$ to $3.28 \%(\mathrm{P}<0.01)$, and from $2.30 \%$ to $2.86 \%(\mathrm{P}<0.01)$, respectively (Figures $1 \mathrm{e}, \mathrm{f})$. The equipment used for fish mincing tends to produce meat with higher mineral matter than the meat deboned manually due to the mechanical pressure to remove the meat along the vertebrae, besides grinding some bones that can be incorporated into the flesh (Nurul et al., 2010). The ash content of the fried snacks is similar to those found in other types of snack fish $(2.7 \%$ to 5.9\%) (Siaw et al., 1985; Yu et al., 1994; King, 2002; Nurul et al., 2010; Neiva et al., 2011).

The carbohydrate content of the snacks was estimated by difference and ranged from $66.74 \%$ to $75.87 \%$. From the values obtained in the chemical composition, the caloric values

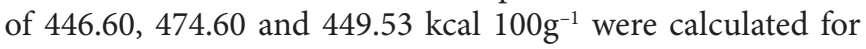
the formulations $20 / 80,30 / 70$, and $40 / 60$, respectively. The recommended daily carbohydrate intake for adults (aged from 19 to 50 ) is about $250 \mathrm{~g} \mathrm{day}^{-1}$, which is based on 2,000 calories a day (National Research Council, 1989). For all treatments, it was found that the consumption of a daily serving of $100 \mathrm{~g}$ snack is approximately one-quarter of the energy and half the carbs of the adult requirements; thus it is considered a highenergy food. A study on fried snack made with MF of marine fish had energy values similar to those of the present study (518.07 kcal.100 g ${ }^{-1}$ ) (Neiva et al., 2011). In snacks made with other types of MF, the carbohydrate content varied from $59.74 \%$ to $78.18 \%$ (Nurul et al., 2009, 2010; Neiva et al., 2011), and therefore close to the values found in the present study. Snacks made mainly with starch may absorb oil during frying, which will result in a high caloric value (Martinez et al., 1997).

The inclusion of 20 to $40 \%$ MF of Nile tilapia in the snacks decreased $(\mathrm{P}<0.01)$ the sensory acceptance regarding the attributes flavor, texture, overall acceptance, and willingness to purchase (Figure 2). On the other hand, there was no significant difference $(\mathrm{P}>0.05)$ in the attribute odor, with scores ranging from 6.53 to 6.80 (like moderately).

Although the formulation with $40 \%$ inclusion of MF obtained lower scores for all attributes, the score values were above 5 (neither liked - or disliked), and it was thus considered an acceptable product. This result is better than the one reported by Yu et al. (1994), who observed that the inclusion of more than $10 \% \mathrm{MF}$ of Nemipterus tolu in fish snacks was not accepted by the panelists.

The sensory evaluation of color showed quadratic variation with the best results in the snacks made with $30 \% \mathrm{MF}$ (7.35 - like moderately) although this result is not relevant as compared with that of the formulation containing 20\% MF (Figure 2a). The lowest scores obtained for the color of the snacks with $40 \%$ MF (6.38 - like slightly) may be due to the darker color observed for the samples of this treatment, which was accentuated during frying. Kyaw et al. (2001) observed that the overall acceptance, texture, color, and flavor of fish snacks made with tapioca starch were not affected by temperature and cooking time $\left(100^{\circ} \mathrm{C}\right.$ for $100 \mathrm{~min})$.

The water activity (Aw) of the snacks showed quadratic increase $(\mathrm{P}<0.01)$ from 0.39 to 0.48 with the inclusion of 20 to $40 \%$ MF (Figure 3a). Water activity values below 0.6 inhibit microbial growth (Franco \& Landgraf, 2004), and, consequently, the snacks of all treatments had good preservation characteristics. Snacks made with MF of marine fish also showed low water activity (0.36) (Neiva et al., 2011). Snacks made with MF of trout (Oncorhynchus mykiss) had water activity values between 0.13 and 0.15 (Shaviklo et al., 2011). A number of factors such as the presence of starch in the formulation and drying and frying processes can lead to low water activity of snacks. Despite of that, other chemical and enzymatic reactions can occur during storage, including lipid oxidation, altering the sensory attributes (Shaviklo et al., 2011).

The increase in MF levels caused a quadratic increase $(\mathrm{P}<0.01)$ in the hardness of the snacks with some stability for the samples containing up to $30 \% \mathrm{MF}$, but hardness increased with the inclusion of $40 \%$ MF (Figure $3 \mathrm{~b}$ ). The increase in hardness may have been one of the factors responsible for the lower acceptance of texture of the snacks containing $40 \%$ MF. Nurul et al. (2009) observed that increasing the amount of minced catfish (Pangasius hypophthalmus) increased the hardness of snacks.

No significant difference was observed in the oil absorption of the fried snacks ( $\mathrm{P}>0.05$ ) with the inclusion of 20 to $40 \%$ MF of tilapia, which ranged from 110.14 to $113.48 \%$. Oil absorption depends on the food (shape, density), oil (viscosity and type), and time and temperature of frying (Paul et al., 1997; 
(a)

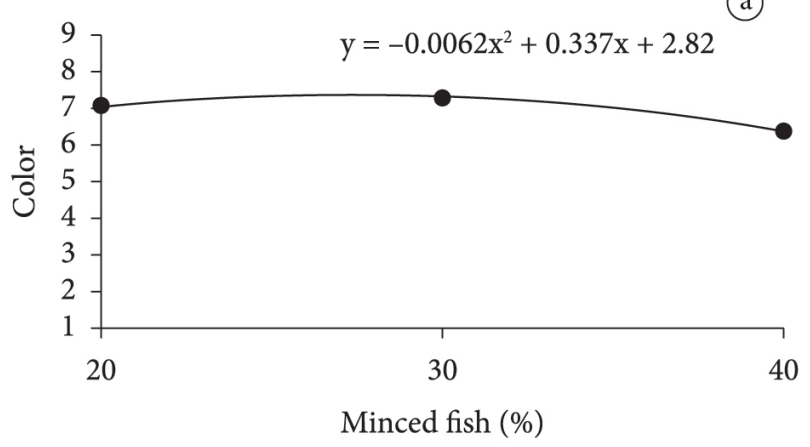

(c)

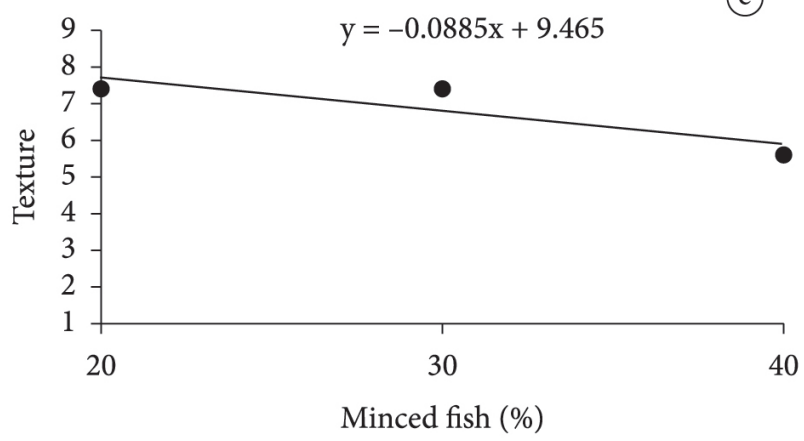

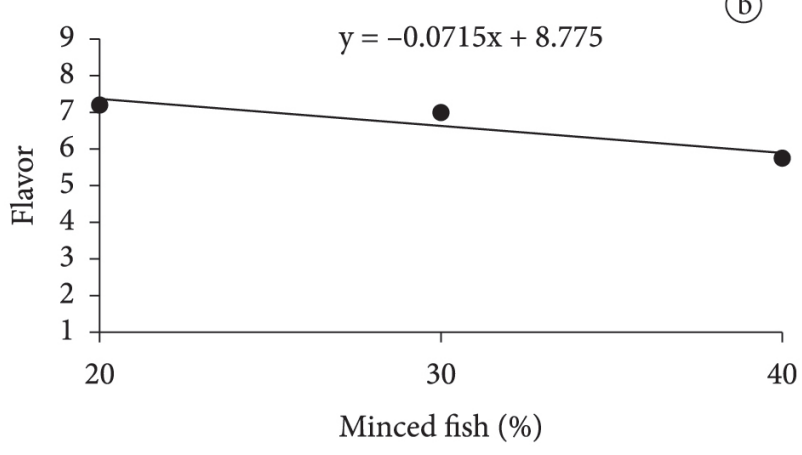

(d)

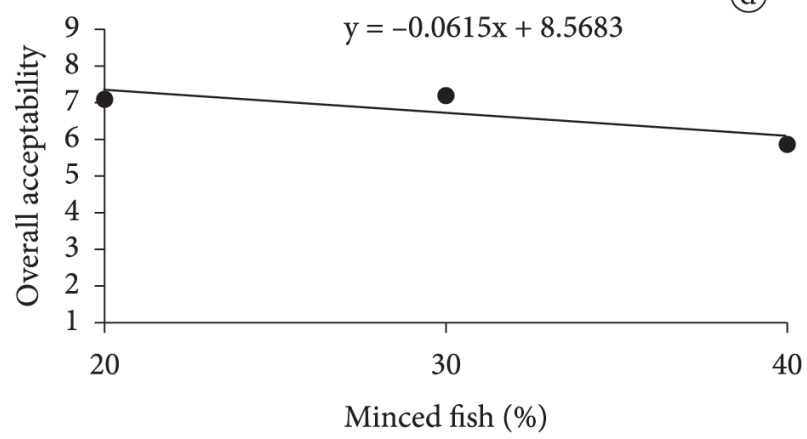

(e)

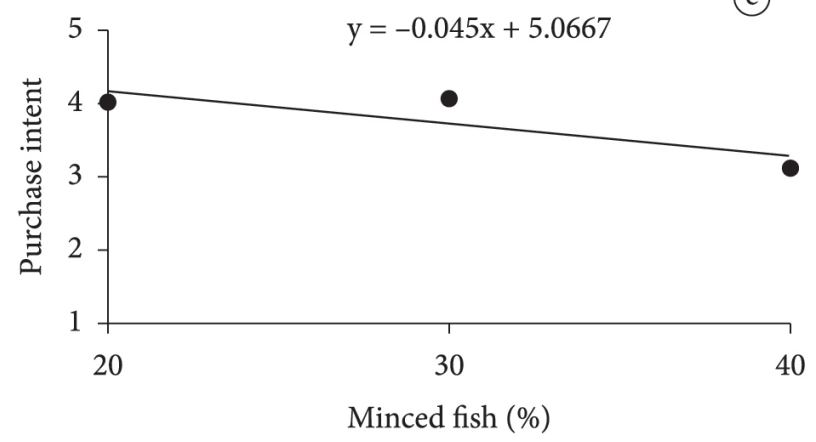

Figure 2. Sensory evaluation of color (a), flavor (b), texture (c), overall acceptance (d) (1 - extremely dislike to 9 - extremely like) and purchase intent (e) (1 - certainly not buy to 5 - certainly buy) of fried fish snacks with 20 to $40 \%$ inclusion of MF of Nile tilapia.

(a)
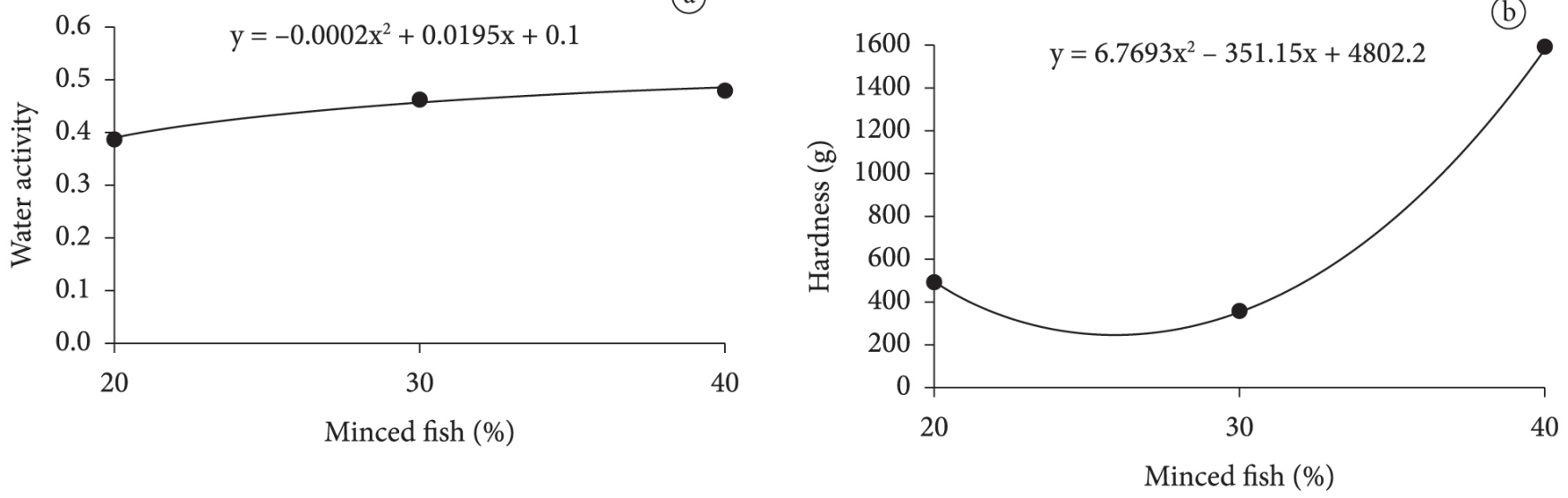

Figure 3. Water activity of non-fried snacks (a) and instrumental texture (b) of fried snacks with 20 to $40 \%$ inclusion of MF of Nile tilapia. 
Damy \& Jorge, 2003). Foods with a high initial fat content do not absorb much oil during frying and the lower the moisture content, the lower the linear expansion ratio and oil absorption (Paul et al., 1997). In the present study, once the temperature $\left(200{ }^{\circ} \mathrm{C}\right)$, frying time $(4 \mathrm{~s})$, and the type of oil were the same for all treatments, probably there was no influence on the oil absorption. Furthermore, the change in the snack composition with the inclusion of 20 to $40 \%$ MF was not enough to cause changes in the oil absorption.

\section{Conclusions}

- The present study demonstrates that it is possible to include $20-40 \%$ of MF of Nile tilapia in snacks without affecting their physicochemical quality.

- The inclusion of $40 \% \mathrm{MF}$ caused a decrease in the overall acceptance of the snacks, but the absolute values indicate that the product is acceptable by consumers.

\section{References}

Association of Official Analytical Chemistry - AOAC. (1999). Official methods of analysis of AOAC. 16th ed. Washington.

American Public Health Association - APHA. (1992). Compendium of methods for the microbiological examination of foods. 3th ed. Washington.

Barreto, P. L. H., \& Beirão, L. H. (1999). Influência do amido e carragena nas propriedades texturiais de surimi de tilápia (Oreochromis sp.). Ciência e Tecnologia de Alimentos, 19(2), 183-188. http://dx.doi. org/10.1590/S0101-20611999000200005

Brasil, Ministério da Pesca e Aquicultura. (2011). Boletim Estatístico da Pesca e Aquicultura 2011. Brasília. Retrieved from http://www. mpa.gov.br/index.php/informacoes-e-estatisticas/estatistica-dapesca-e-aquicultura

Cheow, C. S., Yu, S. Y., Howell, N. K., Man, Y. C., \& Muhammad, K. (1999). Effect of fish, starch and salt contents on the microstructure and expansion of fish crackers ('keropok'). Journal of the Science of Food and Agriculture, 79(6), 879-885. http://dx.doi.org/10.1002/ (SICI) 1097-0010(19990501)79:6<879::AID-JSFA295>3.0.CO;2-P

Cheow, C. S., \& Yu, S. Y. (1997). Effect of fish protein, salt, sugar, and monosodium glutamate on the gelatinization of starch in fish-starch mixtures. Journal of Food Processing and Preservation, 21(2), 161177. http://dx.doi.org/10.1111/j.1745-4549.1997.tb00774.x

Damy, P. C., \& Jorge, N. (2003). Absorção de óleo de soja refinado e gordura vegetal hidrogenada durante o processo de fritura descontínua de batata chips. Alimentos e Nutrição, 14(1), 23-26.

Dehghan-Shoar, Z., Hardacre, A. K., \& Brennan, C. S. (2010). The physico-chemical characteristics of extruded snacks enriched with tomato lycopene. Food Chemistry, 123(4), 1117-1122. http://dx.doi. org/10.1016/j.foodchem.2010.05.071

Food and Agriculture Organization - FAO. (2001). Codex Stan 222: norma para galletas de pescado marino y de agua dulce y de mariscos crustáceos y moluscos. Rome.

Franco, B. D. G. M., \& Landgraf, M. F. (2004). Microbiologia dos alimentos. São Paulo: Atheneu. 182 p.

Instituto Adolfo Lutz - IAL. (2008). Métodos físico-químicos para análise de alimentos. São Paulo: Núcleo de Informação e Tecnologia.

King, M. A. (2002). Development and sensory acceptability of crackers made from the big-eye fish (Branchydeuterus auritus). Food and Nutrition Bulletin, 23(2), 317-340. PMid:12362597

Kyaw, Z. Y., Yu, S. Y., Cheow, C. S., Dzulkifly, M. H., \& Howell, N. K. (2001). Effect of fish to starch ratio on viscoelastic properties and microstructure of fish cracker ('keropok') dough. International
Journal of Food Science and Technology, 36(7), 741-747. http://dx.doi. org/10.1046/j.1365-2621.2001.00481.x

Martinez, I., Olsen, R. L., Nilsen, H., \& Sorensen, K. (1997). Seafood: fulfilling market demands. Outlook Agriculture, 26(2), 104-114.

Meilgaard, M., Civille, G. V., \& Carr, T. B. (1999). Sensory evaluation techniques. 3th ed. Boca Raton: CRC Press. http://dx.doi. org/10.1201/9781439832271

National Research Council. (1989). Recommended Dietary Allowances. 10th ed. Washington: National Academy Press.

Neiva, C. R. P., Machado, T. M., Tomita, R. Y., Furlan, E. F., Lemos Neto, M. J., \& Bastos, D. H. M. (2011). Fish crackers development from minced fish and starch: an innovative approach to a traditional product. Ciência e Tecnologia de Alimentos, 31(4), 973-979. http:// dx.doi.org/10.1590/S0101-20612011000400024

Nurul, H., Aminah, A., \& Babji, A. S. (2001). Substitution of tapioca flour with surimi powder in traditional crackers (Keropok Palembang). In Proceedings of the 16th Conference Nutrition Society of Malaysia, Malaysia, Kuala Lumpur. PMCid:PMC3249402

Nurul, H., Boni, I., \& Noryati, I. (2009). The effect of different ratios of Dory fish to tapioca flour on the linear expansion, oil absorption, colour and hardness of fish crackers. International Food Research Journal, 16, 159-165.

Nurul, H., Leng, L. A., Yee, C. X., \& Herpandi. (2010). Chemical composition, colour and linear expansion properties of Malaysian commercial fish cracker (keropok). Asian Journal of Food and AgroIndustry, 3(5), 473-482.

Oliveira Filho, P. R. C., Fávaro-Trindade, C. S., Trindade, M. A., Balieiro, J. C. C., \& Viegas, E. M. M. (2010). Quality of sausage elaborated using minced Nile tilapia submmitted to cold storage. Scientia Agricola, 67(2), 183-190. http://dx.doi.org/10.1590/S010390162010000200009

Paul, S., Mittal, G. S., \& Chinnan, M. S. (1997). Regulating the use of degraded oil/fat in deep-fat/oil food frying. Critical Reviews in Food Science and Nutrition, 37(7), 635-662. PMid:9408730. http://dx.doi. org/10.1080/10408399709527793

Rado, E., Wong, L., Gallo, M., \& Castro, R. (1989). Influencia de la cantidad de agua en la textura crocante de la hojuela de pescado. Boletín de Investigación del Instituto Tecnologico Pesquero del Perú, 3(1), 107-112.

Shaltout, O. E. (1993). Chip-like cod based crackers: acceptability and chemical composition. LWT - Food Science and Technology, 26(6), 17-21. http://dx.doi.org/10.1006/fstl.1993.1108

Shaviklo, G. R., Thorkelsson, G., Rafipour, F., \& Sigurgisladottir, S. (2011). Quality and storage stability of extruded puffed corn-fish snacks during 6-month storage at ambient temperature. Journal of the Science of Food and Agriculture, 91(5), 886-893. PMid:21384356. http://dx.doi.org/10.1002/jsfa.4261

Siaw, C. L.; Idrus, A. Z., \& Yu, S. Y. (1985). Intermediate technology for fish cracker ('keropok') production. International Journal of Food Science and Technology, 20(1), 17-21. http://dx.doi. org/10.1111/j.1365-2621.1985.tb01898.x

Taewee, T. K. (2011). Cracker "Keropok": a review on factors influencing expansion. International Food Research Journal, 18(3), 855-866.

Yu, S. Y., Mitchell, J. R., \& Abdullah, A. (1981). Production and acceptability testing of fish crackers ('keropok') prepared by the extrusion method. International Journal of Food Science and Technology, 16(1), 51-58. http://dx.doi. org/10.1111/j.1365-2621.1981.tb00995.X

Yu, S. Y., Yeoh, K. C., \& Terushige, M. (1994). Utilization of proteins from fishball processing washwater in fish crackers ('keropok'). Journal of Food Processing and Preservation, 18(6), 453-459. http:// dx.doi.org/10.1111/j.1745-4549.1994.tb00267.x 